\title{
Summary
}

\section{ORGANIZATION OF STUDENTS REFLECTIVE ACTIVITY AT THE MICROBIOLOGY, VIRUSOLOGY AND IMMUNOLOGY} DEPARTMENT

Hancho O.V., Kovalenko N.P., Zvyagolska I.M., Hancho A.D., Bobrova N.O.

Keywords: reflexive activity, method of reflexive polylogue, professional training of future doctors, reflexive exercises.

At present the development of critical thinking is crucial for individuals who are eager to get involved into productive interaction with the outside world, who are able to assess their own achievements objectively throughout the learning process, to analyze ways resulting in successes or fails, set purposes for selfimprovement and self-development. There is a growing literature in medical education suggesting that reflection improves learning and performance in essential competencies to a growing literature in medical education suggesting that reflection improves learning and performance in essential competencies. Therefore fostering students' reflective thinking is an important component of the educational process. The purpose of this study is to provide the grounds for organizing reflective activities for the future healthcare professionals in the context of their professional training. The experiment included 90 second-year students of Dentistry Faculty divided into two groups: test group involved 50 respondents and control group comprised 40 students. The method of studying reflexive abilities was based on applying teachers' assessment and students' selfassessment of students' educational and cognitive activities including the following structural components: awareness of the learning outcomes and whether the outcomes are consisted with intended goals, selfanalysis and self-assessment of individual activities and activities during team working. Each component was evaluated by five-score scale. Teachers also used the method of reflexive polylogue. The probability of the difference between the groups was determined by Student's t test. Designing of effective reflection requires time, effort and willingness; such activity should not feel like busy work or an add-on activity. The article elucidates the ways and principles of organization of reflective activity for future doctors. We offered some types of exercises aimed at developing the reflective skills for further professional work. We also detailed methodological recommendations and technoques on the organization of reflective activity for the dental students. The study has demonstrated that the highest level of reflexive skills in students corresponded to $3.4 \pm 0.7$ scores that are quit sufficient for productive learning. It is through reflection the methods and results of own learning outomes are analyzed and assessed. Reflection is a skill, which requires development and can be applied broadly in medical education.

DOI 10.31718/2077-1096.21.3.238

УДК 378.14:611

\section{Гринь В.Г.}

\section{СТАНОВЛЕННЯ I НАДБАННЯ КАФЕДРИ АНАТОМІЇ ЛЮДИНИ ПОЛТАВСЬКОГО ДЕРЖАВНОГО МЕДИЧНОГО УНІВЕРСИТЕТУ 3 МОМЕНТУ Ї̈̈ ЗАСНУВАННЯ}

Полтавський державний медичний університет

У своєму становленні й розвитку Полтавський державний медичний університет пройшов тернистий шлях від одонтологічного фракультету, створеного на базі Харківської медичної академії в 1921 році, до провідного спеціалізованого закладу із підготовки лікарів, який в 2021 році відзначає свій 100-річний ювілей з дня заснування. В 1950 році кафедра анатомії людини отримала свою власну базу. Наукова тематика кафедри охоплювала широкий спектр питань, була присвячена вивченню будови залоз слизових оболонок і вегетативної нервової системи, вивченню лімфооїної тканини початкового відділу травної системи, обладнані мікроскопічна, гістологічна, гістохімічна і фотолабораторії, організований музей кафедри. Науковцями були розроблені та виготовлені різноманітні пристосування та методики для проведення морфологічних досліджень, що дозволило опублікувати чисельні методичні рекомендації, навчальні посібники, проводити наукову роботу по захисту дисертацій на здобуття ступеню кандидата та доктора медичних наук. Окрасою кафедри анатомії людини ПДМУ є сучасний анатомічний музей, який в теперішньому вигляді сорормований у 2005 році, відомий за кордоном. Музей викликає зацікавленість в абітурієнтів під час проведення «Дня відкритих дверей», приймає студентів-біологів інших ВНЗ. У діяльності кафедри анатомії людини тісно поєднуються педагогічний процес і виховна робота.

Ключові слова: Полтавський державний медичний університет, кафедра анатомії людини, наукова робота, вчені-анатоми.

Довгий і славний шлях розвитку пройшов Полтавський державний медичний університет (ПДМУ) від одонтологічного фракультету, створеного на базі Харківської медичної академії в 1921 році до провідного спеціалізованого закладу із підготовки лікарів, який в 2021 році відзначає свій 100-річний ювілей з дня заснування.
У своєму становленні й розвитку Полтавський державний медичний університет пройшов тернистий шлях, який умовно можна поділити на сім періодів: перший - із часу організації одонтологічного факультету при Харківській медичній академії (1921-1931); другий - із моменту перетворення факультету в самостійний 
Харківський стоматологічний інститут (19311941); третій - період евакуації до м. Фрунзе (Киргизька РСР) і його функціонування як фракультету Киргизького медінституту (1941-1944); четвертий - реевакуація до м. Харкова після його звільнення від фашистських загарбників, відновлення баз підготовки кадрів і подальший розвиток наукових досліджень (1944-1967); п'ятий - переведення до Полтави й перетворення в Полтавський медичний стоматологічний інститут (1968-1993); шостий - від перетворення інституту в Українську медичну стоматологічну академію (УМСА) (1994-2020), сьомий - із 2021

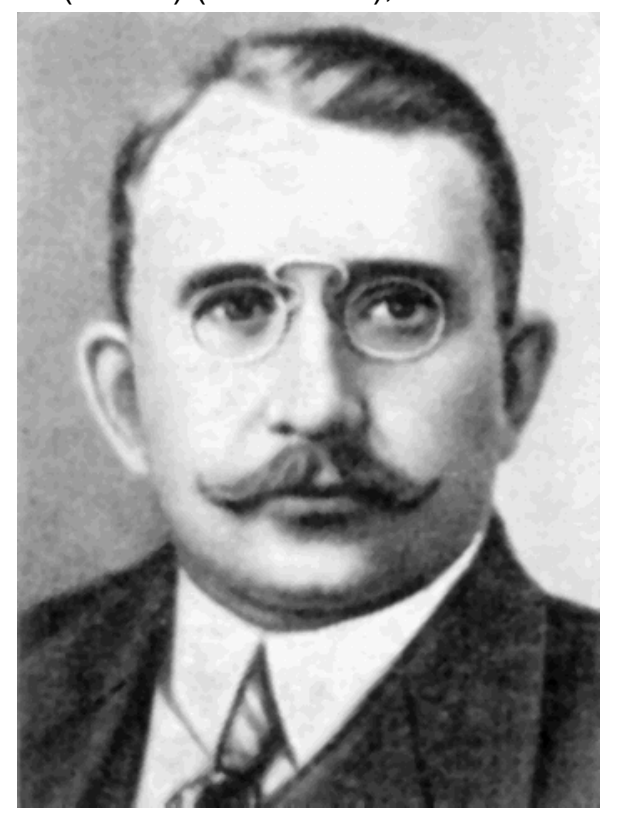

Рис. 1. Володимир Петрович Воробйов (27.07.1876 Одеса - 31.10.1937, Харків) - анатом, член АН УРСР, заслужений профессор СРСР.

В послідуючі роки кафедрою завідували, також по сумісництву, доцент К.С. Філонова (1937-1940), профресор Ф.А. Волинський (19401941), доцент Н.А. Рудинський (1941-1945), під час евакуації інституту в м. Фрунзе та після його реевакуації - професор Р.Д. Синельников (1946-1950).

В 1950 році кафедра отримала свою власну базу. 3 цього часу і до 1963 року кафедру знову, але вже самостійно очолила доцент Клавдія Симонівна Філонова, хороший організатор навчального процесу і прекрасний лектор. Наукова тематика була присвячена вивченню будови залоз слизових оболонок і вегетативної нервової системи. Будучи проректором 3 навчальної та наукової роботи інституту, К.С. Філонова виконувала докторську дисертацію, нагороджена медалями та значком «Відмінник охорони здоров'я». Доцент Я.Р. Синельников виконав докторську, а асистенти Є.М. Ковбаса (1955), С.П. Шапіро (1955), В.П. Страхова (1965) - кандидатські дисертації. Співробітники кафедри опублікували близько 100 робіт. Філонова К.С. написала ряд розділів для стислого підручника з анатомії людини В.П. Воробйова р., від реорганізації УМСА в Полтавський державний медичний університет $[5,8,12]$.

До 1950 року кафедра анатомії людини не мала власної бази і розміщувалась в приміщеннях кафедр анатомії людини Харківського медичного інституту. 31931 по 1937 р. за сумісництвом кафедру очолював видатний вченийанатом, Член ЦВК УРСР, лауреат премії ім. B.І. Леніна академік Академії наук УРСР, доктор медичних наук, професор Володимир Петрович Воробйов (рис. 1) [6, 7].

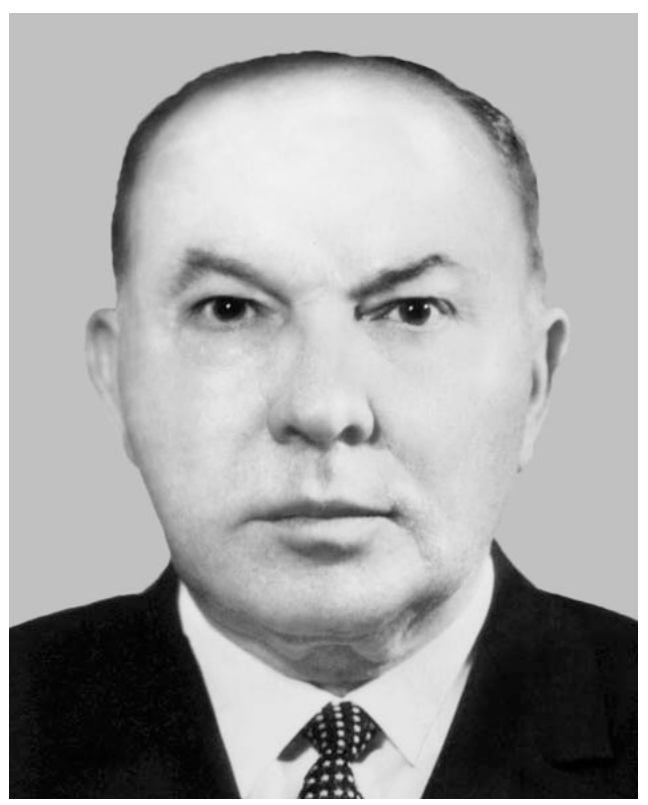

Puс. 2. Косицин Іван Іванович (25.09(08.10)1906, с. Шацькі Борки Тамбов. губ., нині Рязан. обл., РФ 09.01.1978, Полтава, Україна).

та Р.Д. Синельникова [12].

У 1963 році завідувачем кафедри анатомії людини було обрано видатного вченогоанатома, талановитого педагога, доктора медичних наук, професора Івана Івановича Косицина (рис. 2).

На кафедрі ним була створена гістохімічна лабораторія, навчені лаборанти. Співробітники кафедри зайнялися вивченням лімфоїдної тканини початкового відділу травної системи: слизової оболонки язика, губ, щік, привушної і під'язикової залоз. Ряд аспірантів і співробітників клінічних кафедр виявили бажання виконувати на кафедрі анатомії людини морфологічні фрагменти дисертаційних робіт.

У 1967 році при переведенні інституту в м. Полтаву переїхали тільки три співробітника кафедри: сам професор І.І. Косицин, асистент кандидат медичних наук Є.М. Ковбаса і асистент Ю.П. Костиленко, який роком раніше закінчив інститут і залишився при ньому на науково-педагогічну роботу. Відразу ж було проведено доукомплектування штату кафедри. Асистентами, а потім доцентами було обрано 
П.М. Ковтуновського і Ю.О. Максимука, асистенти - Н.А. Волобуєв і Є.В. Ковальов. В аспірантуру були зараховані А.В. Яланский і М.А. Волобуєв. Територія кафедри була достатньою для навчального процесу. Чотири препарувальних зали були оснащені навчальними наочними посібниками, обладнані мікроскопічна, гістологічна, гістохімічна і фротолабораторії, також організований музей кафедри.

Колектив кафедри продовжив вивчення морфології лімфоїдної тканини порожнини рота і суміжних органів. Будучи великим вченимлімфологом, професор І.І. Косицин, вивчаючи реакцію лімфоїдної тканини привушної залози кролика на сенсибілізацію кінської сироватки і культури стрептокока, сам проводив досліди на тваринах, фотографував мікропрепарати, проявляв плівки, друкував фото, скрупульозно вів протоколи дослідження, виконував замальовки з мікропрепаратів. При консультації та під керівництвом професора І.І. Косицина в полтавський період виконано 2 докторські та 10 канди-

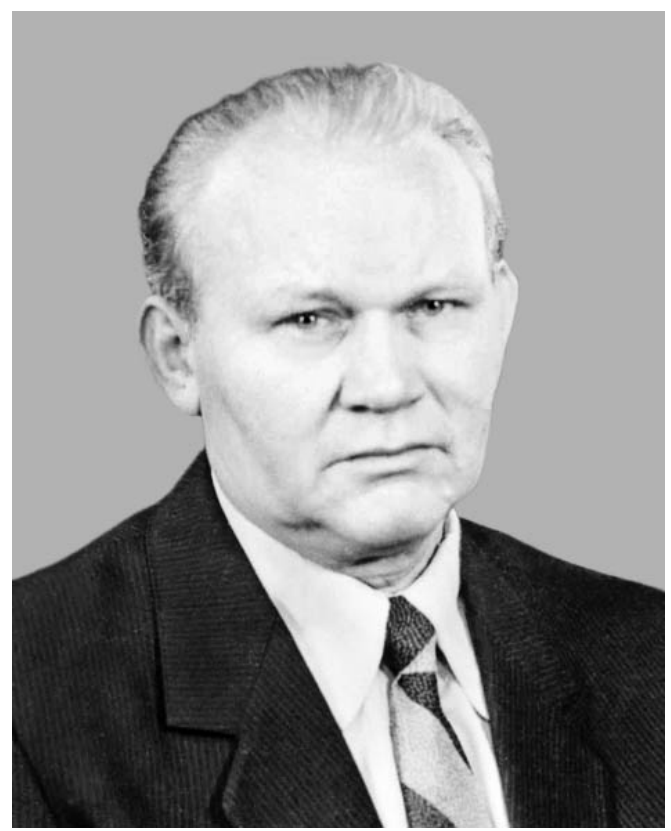

Рис. 3. Максимук Юрій Олександрович (23.04.1930, с. Піща, нині Шацького р-ну Волин. обл. - 05.02.2007, Полтава).

Виготовлено пристосування для фріксації скляних ножів до мікротому ПМС-2 з метою отримання напівтонких зрізів з епоксидних блоків; розроблені методи поліхромної багатошарової графічної і пластичної реконструкції, методи підготовки і отримання препаратів для вивчення епітеліальних компонентів і кровоносного русла за допомогою скануючого електронного мікроскопа, що дозволило опублікувати методичні рекомендації. Методика візуального вивчення тривимірної будови екзокринних залоз тварин і людини (Ю.П. Костиленко, М.С. Скрипніков, Є.А. Дев'яткін, 1983). На основі цих запропонованих методів виконаний цілий ряд датських дисертацій. Успішно захистили кандидатські дисертації аспірант А.В. Яланський (1972), асистент Ю.П. Костиленко (1972), аспірант М.А. Волобуєв (1973), асистент Н.А. Волобуєв (1974), та ін. I докторські дисертації: доцент Ю.О. Максимук (1971), доцент П.М. Ковтуновський (1973) [12, 21].

У 1973 році завідувачем кафедри за конкурсом був обраний доктор медичних наук, професор Юрій Олександрович Максимук (рис. 3).

Колектив кафедри продовжив обладнання кафедри, оснащував навчальний процес наочними посібниками, методичною документацією. Було також продовжено подальшу наукову розробку проблеми структурної організації залоз і лімфоїдної тканини початкового відділу травної системи в поєднанні з їх мікроциркуляторним руслом. Кандидатські дисертації виконали асистент Є.В. Ковальов (1978), аспірант В.І. Мітченок (1978), аспірант О.А. Устянський (1980), асистент Є.А. Дев`яткін (1981).

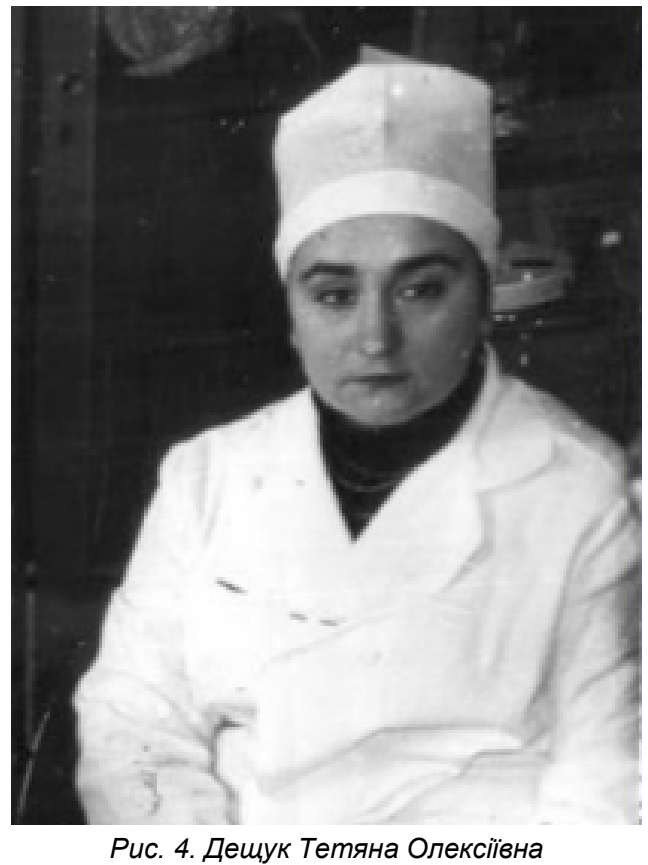

(10.11.1950, Житомир - 08.05.1994, Полтава)

дисертаційних робіт з просторової організації екзокринних і ендокринних залоз. Так, доцент Ю.П. Костиленко виконав докторську дисертацію «Структурне забезпечення секреторного процесу піднебінних слинних залоз щурів» (1984), в якій провів системне вивчення просторово-часової організації екзокринних залоз. Це дозволило йому докладно описати тривимірну структуру епітеліальних компонентів залози, визначити закономірності їхньої просторової упорядкованості та ієрархії. Також безліч кандидатських дисертацій: аспірант Ю.К. Хилько (1987), асистент І.В. Мислюк (1987), аспірант О.В. Качалка (1988), асистент Л.Г. Кривега 
(1988), аспірант О.О. Шерстюк (1990). Це був продуктивний науковий період становлення кафедри анатомії людини.

З 1983 року кафедра розташовується в морфологічному корпусі. Кафедра анатомії має хорошу базу: учбові кімнати, які оснащені секційними столами, безтіньовими лампами, електрифрікованими стендами. В підвальному приміщенні розміщене сховище анатомічних препаратів. Кафедра має анатомічний музей, конференц-зал, створена галерея портретів вчених-анатомів, експозиція становлення людини, виконаних відомими художниками Полтави, організовано куточок Воробйова В.П. та інші інформаційні стенди [12].

У 1993 році зі складу кафедри відділилася кафредра анатомії людини стоматологічного факультету, яку очолила випускниця інституту доктор медичних наук Дещук Тетяна Олексіївна (рис. 4).

В 1990 році Дещук Т.О. успішно захищає докторську дисертацію «Структурнофункціональні зміни міокарда і інтрамурального нервового апарата серця в умовах експериментальної патології (інфраркт міокарда, коарктація аорти, внутрішньо перикардіальний стеноз легеневого стовбура)». Далі вона професор кафедри оперативної хірургії та топографрічної анатомії (1990), згодом завідувачка кафредри анатомії людини стоматологічного факультету, а потім і медичного (1993). Поєднує посаду завідувачки кафредрою з громадською роботою - $€$ куратором наукового студентського товариства інституту, формується висококваліфікованим анатомом, стає співавтором практикуму для студентів. На сучасному науковотеоретичному і високому методичному рівні читає лекції для студентів. Під її керівництвом проведена реконструкція приміщення кафредри, тематично оформлені навчальні кімнати, проведено переоформлення одного з анатомічних музеїв кафедри. Бере активну участь у проведенні на базі кафедри наради завідувачів кафедр анатомії людини медичних вузів України. Вона переростає у зрілого науковця, консультує виконання докторської дисертації доцента i керує трьома кандидатськими дисертаціями асистентів кафедри. Виступає з доповідями на наукових форумах різних рівнів, обирається заступником голови Полтавського обласного наукового товариства анатомів, гістологів, ембріологів та топографроанатомів України. За сумлінну працю була нагороджена медаллю «За доблесну працю», знаком «Відміннику охорони здоров'я» [14].

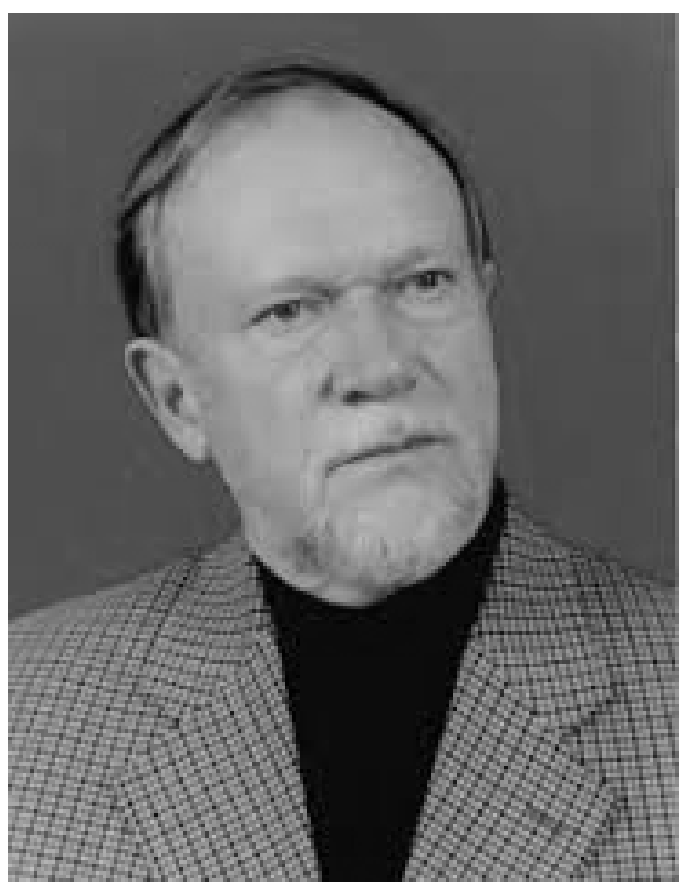

Рис. 5. Костиленко Юрій Петрович (04.10.1938, м. Ромни, Сумська обл.).

В 1994 році завідувачем кафедри анатомії людини призначено доктора медичних наук, професора Юрія Петровича Костиленка (рис. 5).

Костиленку Ю.П. належить пріоритет в описанні наскрізних внутрішньоклітинних отворів в стінках вивідних протоків піднебінних залоз. Широке застосування методів багатошарової двовимірної та тривимірної реконструкції дозволило здійснити розшифровку конструкції мікроциркуляторного русла слинних залоз, встановити топологічні відносини між резистивними, обмінними та ємнісними ланками мікроциркуляторного русла в структурнофункціональних одиницях екзокринних залоз.

Костиленко Ю.П. займав посаду голови Полтавського обласного відділення наукового товариства анатомів, гістологів, ембріологів і топографооанатомів України, член спеціалізованої ради з морфології при Харківському державному медичному університеті. Натепер він професор кафедри і завідувач наукової лабораторії по вивченню проблем етіології та патогенезу карієсу. Брав участь у заснуванні лабораторії електронної мікроскопії. Професор Ю.П. Костиленко $є$ досвідченим спеціалістом з електронної мікроскопії, під його керівництвом кафедра працювала над питаннями вивчення структурних основ фрункціонування слинних залоз, проблемами мікроциркуляції, структурнофункціональних одиниць залоз порожнини рота і травного каналу (рис. 6). 


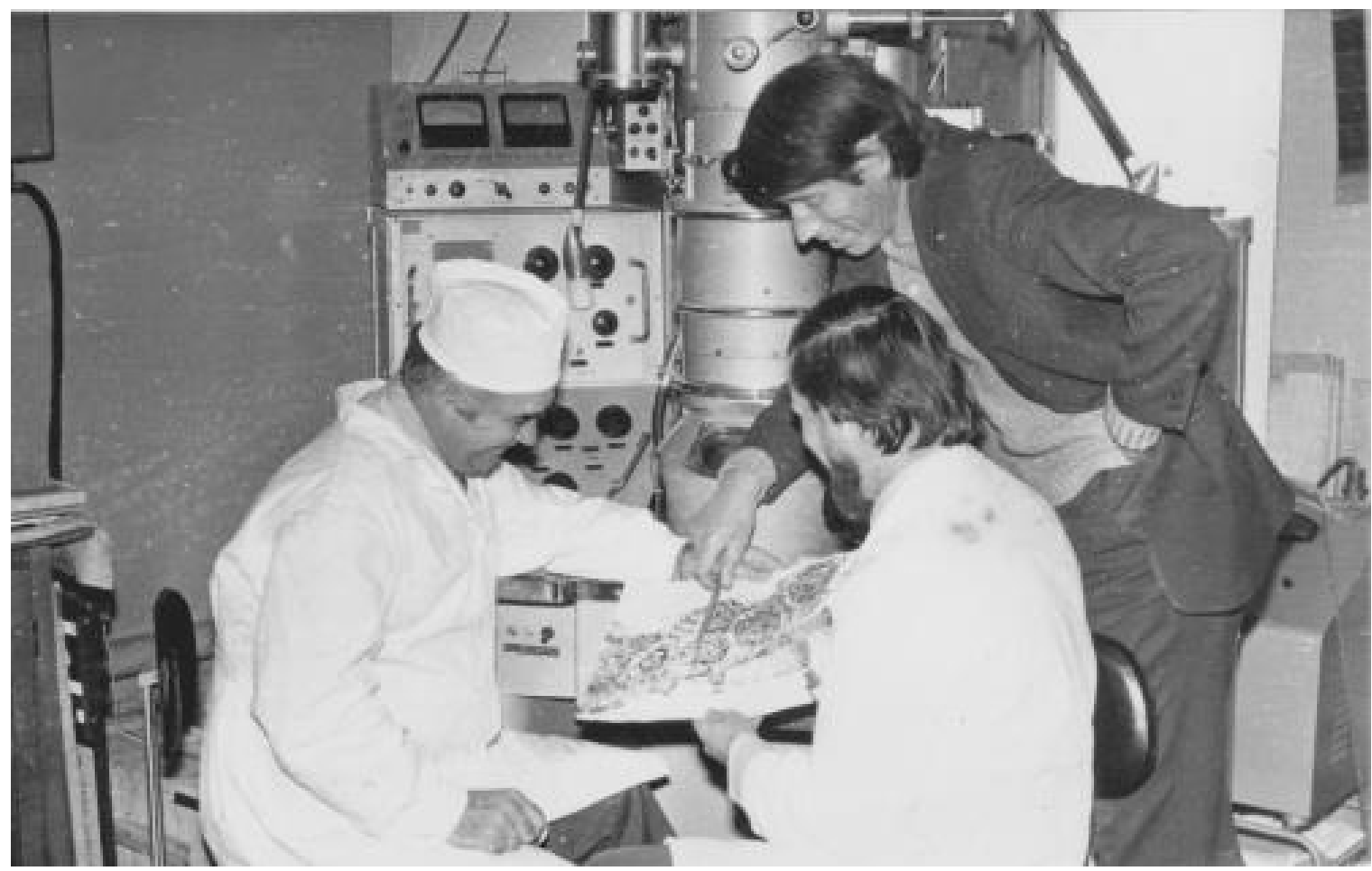

Puс. 6. Робота в лабораторії електронної мікроскопії (на фото зліва-направо Скрипніков М.С., Костиленко Ю.П., Ковальов Є.В.).

Під керівництвом професора Ю.П. Костиленка, починаючи з 1993 року, успішно захистили докторські дисертації 8 науковців: Колбасин П.М. (1993), Мітченок В.І. (1996), Шерстюк О.О. (2002), Єрошенко Г.А. (2010), Старченко І.І. (2010), Степанчук А.П. (2013), Боягіна О.Д. (2018), Гринь В.Г. (2021). А починаючи з 1980 року було успішно захищено 22 дисертації на здобуття наукового ступеня кандидата медичних наук: Устянський О.О. (1980), Дев'яткін Є.О. (1981), Мислюк І.В. (1987), Качалка О.В. (1988), Кривега Л.Г. (1988), Шерстюк О.О. (1990), Єрошенко Г.А. (1993), Пелипенко Л.Б. (1998), Степанчук А.П. (1998), Дейнега Т.Ф. (1998), Тумакова О.Б. (1998), Старченко І.І. (2000), Прилуцький О.К. (2004), Бойко І.В. (2004), Власова О.В. (2004), Азмі Махмуд Алі Хусейн (2009), Тихонова О.О. (2009), Удальцова X.O. (2010), Петренко А.I. (2011), Анопрієва Н.М. (2013), Гринь В.Г. (2013), Саркісян Е.Г. (2016) $[9,10]$.

Вагомий внесок зробив у створенні анатомічного музею кафедри анатомії людини. Велика кількість ін'єкційно-корозійних препаратів та тривимірних моделей органів підготовлена ним та надана для опанування студентамимедиками глибин анатомії [2, 11, 20].

32006 року і по цей час посаду завідувача кафредрою анатомії людини займає доктор медичних наук, професор Олег Олексійович Шерстюк (рис. 7).

У 2002 році захистив дисертацію на здобуття наукового ступеня доктора медичних наук на тему «Морфологічний стан слизової оболонки пілоричного відділу шлунку і ясенних сосочків в нормі та при виразковій хворобі». Саме тому науковим напрямком його подальшої професійної діяльності стала така тематика, як стереоморфологія та структурне забезпечення функції екзокринних залоз та мікроциркуляторного русла слизових оболонок порожнини рота та внутрішніх органів.

Шерстюк О.О. виконує обов'язки голови академічної проблемної комісії за фрахом «Морфологія», в різні роки був членом спеціалізованої вченої ради при Харківському національному медичному університеті, Дніпропетровській державній медичній академії, Сумському державному університеті.

Під час свого завідування на кафедрі Олег Олексійович підготував 5 кандидатів наук: Свінцицька Н.Л. (2007), Блищавенко Ю.В. (2008), Пілюгін А.В. (2009), Устенко Р.Л. (2014), Білаш В.П. (2018) і на цей час має учнів-аспірантів, для яких він $є$ взірцем кваліфрікованого профресіонала, володіючи високим рівнем педагогічної майстерності, гарного керівника й порядної людини.

Зі своїми колегами та учнями О.О. Шерстюк реконструював, модернізував анатомічний музей на кафедрі анатомії, який відвідує величезна кількість абітурієнтів, школярів старших класів 3 метою професійної орієнтації, студентів юридичних фракультетів, відвідувачів 3-за кордону. «Родзинкою» анатомічного музею кафедри анатомії людини $€$ велика колекція ін'єкційно-корозійних препаратів внутрішніх органів людини та тварин, за допомогою якої вивчається просторова організація окремих морфологічних структур внутрішніх органів. В зна- 
чній мірі, використання запропонованого способу дозволяє отримати точну об'ємну копію кровоносного русла органу, а також одержати більш якісні препарати, що слугують для подальшого проведення морфологічних досліджень (морфометрія внутрішнього діаметра судин, простежити їх розгалуження, кути відходження, довжину судин, виявлення анастомозів). Головною суттю наукової діяльності професора Шерстюка Олега Олексійовича стала музейна колекція реконструкцій паренхіматозних органів (сльозові залози, передміхурові залози, губні та піднебінні залози), які надають чітке уявлення про просторову організацію залозистих компонентів та архітектоніки кровоносного мікроциркуляторного русла, геометрію просвіту епітеліальних екскреторних протоків залоз [15, 18].

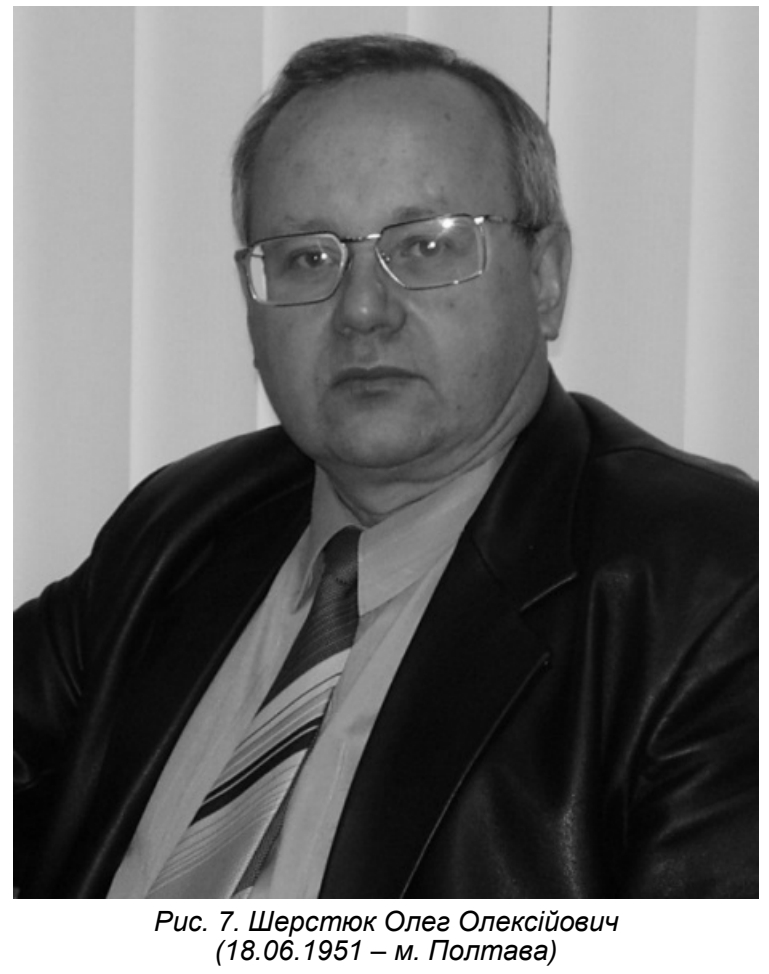

Окрасою кафедри анатомії людини ПДМУ є вищезгаданий сучасний анатомічний музей, який в теперішньому вигляді сорормований у 2005 році і поділений на два розділи: «сухий» та «вологий». Всю експозицію музею можна розділити на такі основні групи: підбір оригінальних кісткових та 3D-препаратів кісток лицьового черепа; препарати суглобів та м'язів; вологі анатомічні препарати внутрішніх органів людини; муміфіковані тотальні препарати; підбір ін'єкційно-корозійних препаратів судинного русла органів грудної, черевної та сечостатевої систем; багатошарові пластичні реконструкції екзокринних залоз (губних, піднебінних, сльозової, передміхурової); двовимірні колажі матеріалів дисертаційних робіт професорськовикладацького складу кафедри анатомії людини; колекція препаратів розвитку людини в он- тогенезі; вади розвитку людського організму; портрети видатних вчених-анатомів; крилаті вислови про медицину латинською мовою.

Усі анатомічні препарати розміщені на стелажах сучасного дизайну, мають електричне підсвічування. Особливу увагу приділено авторефератам дисертаційних робіт професорськовикладацького складу кафедри за останні 50 років; досягненням кафедри у науковій діяльності у вигляді грамот, дипломів, раціоналізаторських пропозицій, патентів, нововведень, інформаційних листів, тощо. Почесне місце займає альбом історії кафедри та студентського наукового анатомічного товариства [2, 3].

У кімнаті «вологих анатомічних препаратів» розміщені шафи з тотальними муміфікованими препаратами - це базове надбання кафедри. $\mathrm{Ha}$ окремих стелажах зібрані ін'єкційнокорозійні препарати судинного русла внутрішніх органів, жовчовивідних шляхів у порівняльному аспекті людей та деяких тварин, які були виготовлені студентами та викладачами кафредри.

Особливий інтерес викликає оригінальний підбір ін'єкційно-корозійних препаратів печінки тварин, яку виготовив доцент Недбай Б.О. Підбір включає близько сорока експонованих препаратів та приблизно така ж кількість міститься у сховищі музею кафедри. Поруч для порівняння експонуються вологі та корозійні препарати печінки людини.

Неабияку зацікавленість музей викликає в абітурієнтів під час проведення «Дня відкритих дверей». Музей також орієнтовано на проведення занять студентів-біологів інших ВНЗ. Про музей знають і за кордоном, за останні роки нас відвідали громадяни Угорщини, Австралії, Ізраїлю, Італії, Німеччини, Англії, Канади, Ірану, Йорданії, Індії, Палестини про що свідчать схвальні відгуки у журналі відвідувань [16].

У діяльності кафедри анатомії людини тісно поєднуються педагогічний процес, наукова і виховна робота $[1,4,13,17,19]$. Зараз колекція музею має особливу цінність, оскільки виготовлення нових препаратів стає досить складним завданням.

Штат кафедри укомплектований повністю згідно штатного розкладу і педагогічного навантаження. На цей день на кафедрі працюють: професори: завідувач кафедри - д.мед.н. Шерстюк О.О., д.мед.н. Костиленко Ю.П., д.мед.н. Степанчук А.П.; д.мед.н., доцент Гринь В.Г.; кандидати медичних наук: доцент Дейнега Т.Ф., доцент Тихонова О.О., доцент Тарасенко Я.А., доцент Свінцицька Н.Л., доцент Білаш В.П., доцент Пілюгін А.В., доцент Устенко Р.Л.; старші викладачі: к.мед.н. Сербін С.І.; викладачі: Федорченко І.Л., Каценко А.Л., Литовка В.В., Корчан Н.О., Підлужна С.А.; старші лаборанти: Северин Ю.М., Стриженок В.П.; підсобні робітники: Каценко Л.Г.; Корольова Л.М.; Михайленко П.І.; Забережна Т.І. 
Натепер співробітники кафедри є співвиконавцями планової ініціативної науководослідної роботи кафедри анатомії людини Полтавського державного медичного університету «Морфо-функціональне вивчення внутрішніх органів людини та лабораторних тварин в різних аспектах експериментальної медицини», № державної реєстрації 012U108258.

Таким чином, кафедра анатомії людини Полтавського державного медичного університету не зупиняється на досягнутому і впевнено крокує далі, ставить перспективні завдання, серед яких підвищення якості навчання, вдосконалення матеріально-технічної бази, продовження славних освітніх традицій.

\section{Література}

1. Bilash VP, Hryn VH, Hryn KV. Tendentsiyi y napryamy $v$ dystantsiyniy osviti. [Trends and directions in distance education]. Realiyi, problemy ta perspektyvy vyshchoyi medychnoyi osvity: materialy navch.-nauk. konf. z mizhnar. uchastyu. Poltava, 2021:26-28. (Ukrainian).

2. Bilash VP, Hryn VH. Znachennya student.s'kykh naukovykh hurtkiv u profesiynomu stanovlenni vypusknykiv-medykiv. [The importance of student research circles in the professional development of medical graduates]. Bioriznomanittya: innovatsiyna diyal'nist' u systemi ekolohiyi y osvity: materialy Vseukr. nauk.-prakt. konf. prysvyachenoyi 60-richchyu zasnuvannya dendroparku zahal'noderzhavnoho znachennya «Kryvoruds'kyy». Poltava, 2021:118-121. (Ukrainian).

3. Deyneha TF, Svintsyts'ka NL, Rohulya VO, Hryn VH. Napryamky udoskonalennya pidhotovky maybutnikh likariv u suchasnykh umovakh na kafedri anatomiyi lyudyny. [Directions for improving the training of future doctors in modern conditions at the Department of Human Anatomy]. Osnovni napryamky udoskonalennya pidhotovky medychnykh kadriv u suchasnykh umovakh: materialy Vseukr. nauk.-prakt. konf. $z$ mizhnar. uchastyu. Poltava. 2015;71-73. (Ukrainian).

4. Dubrovina OV, Sherstyuk OO, Tarasenko YAA, Hryn VH, Horbachenko OB, Toropova AA. Shlyakhy pidvyshchennya yakosti vyshchoyi medychnoyi osvity u pidhotovtsi studentiv stomatolohichnoho fakul'tetu do litsenzovanoho intehrovanoho ispytu. [Ways to improve the quality of higher medical education in preparing students of the Faculty of Dentistry for the licensed integrated exam]. Aktual'ni problemy suchasnoyi vyshchoyi medychnoyi osvity $v$ Ukrayini: navch.-nauk. konf. $z$ mizhnar. uchastyu. Poltava: 2019;76-78. (Ukrainian).

5. Hryn VH, Ryabushko MM, Hryn KV, Ryabushko NO. Diyevist' systemy administruvannya na fakul'teti u formuvanni osobystosti maybutn'oho likarya. [Efficiency of the administration system at the faculty in the formation of the personality of the future doctor]. Ukrayins'kyy stomatolohichnyy al'manakh. 2021;1:103107. (Ukrainian).

6. Hryn VH. V.P. Vorobyovu - 140 rokiv. [V.P. Vorobyov is 140 years old]. Trybuna likarya. 2016;11(218):7. (Ukrainian).

7. Podrezenko O. Istoriya odnoho vchenoho. Volodymyr Petrovych Vorobyov: do 145-richchya vydatnoho vchenoho-anatoma. [History of a scientist. Vladimir Petrovich Vorobyov: to the 145th anniversary of the outstanding scientist-anatomist]. Poltavs'kyy
derzhavnyy medychnyy universytet, Biblioteka. Poltava, 2021, 21 slayd. (Ukrainian).

8. Pokhyl'ko VI, Borovyk OB, Beznosa SP ta in. UMSA - 100. Bibliozanurennya $v$ istoriyu Akademiyi. Ch. 1. [UMSA - 100. Biblio-immersion in the history of the Academy. Part 1]. bibliohr. pokazhch. [Elektronnyy resurs]: [prezentatsiya PowerPoint]. Poltava, 2020, 111 slaydiv. (Ukrainian).

9. Profesor Kostylenko Yuriy Petrovych (do 75-richchya vid dnya narodzhennya). [Professor Yuriy Kostylenko (to the 75th

anniversary of his birth).]. Klinichna anatomiya ta operatyvna khirurhiya. 2013;12(4):131-132. (Ukrainian).

10. Sherstyuk OA, Stepanchuk AP, Hryn VH ta in. Do 80-richchya z dnya narodzhennya talanovytoho vchenoho, nastavnyka dnya narodzhennya talanovytoho vchenoho, nastavnyka bahat'okh pokolin' naukovtsiv profesora Yuriya Petrovycha
Kostylenka! [To the 80th anniversary of the birth of a talented Kostylenka! [To the 80th anniversary of the birth of a talented
scientist, mentor of many generations of scientists, Professor Yuri Petrovich Kostylenko!]. Visnyk problem biolohiyi i medytsyny. 2018;4(1;(146)):13-14. (Ukrainian).

11. Sherstyuk OO, Pidluzhna SA, Svintsyts'ka $\mathrm{NL}$ ta in. Zastosuvannya suchasnykh zasobiv navchannya na kafedri anatomiyi lyudyny. [Application of modern teaching aids at the anatomiyi lyudyny. [Application of modern teaching aids at the
Department of Human Anatomy]. Realiyi, problemy ta perspektyvy vyshchoyi medychnoyi osvity: materialy navch.nauk. konf. Z mizhnar. uchastyu. Poltava, 2021:294-296. (Ukrainian).

12. Skripnikov NS, Del'va VA, Bondarchuk LV i dr. Poltavskiy gosudarstvennyy meditsinskiy stomatologicheskiy institut. [Poltava State Medical Stomatological Institute]. Poltava, 1991, 212 s. (Russian).

13. Skrypnikov AM, Hryn KV, Hryn VH. Znachennya likars'koyi etyky y deontolohiyi u formuvanni osobystosti maybutn'oho likarya. [The importance of medical ethics and deontology in shaping the personality of the future doctor]. Realiyi, problemy ta perspektyvy vyshchoyi medychnoyi osvity: materialy navch.nauk. konf. Z mizhnar. uchastyu. Poltava, 2021:242-244. (Ukrainian).

14. Skrypnikov MS, Maksymuk YuO, Stepanchuk AP. Profesor Tetyana Oleksiyivna Deshchuk (do 10-yi richnytsi vid dnya smerti). [Professor Tetyana Oleksiivna Deschuk (until the 10th anniversary of her death)]. Visnyk problem biolohiyi i medytsyny. 2004;3:3-4. (Ukrainian).

15. Svintsytska NL, Hryn VH, Bilash VP. ta in. Profesor Sherstyuk Oleh Oleksiyovych. [Professor Oleg Sherstyuk]. Visnyk problem biolohiyi i medytsyny. 2021;2(160):13. (Ukrainian).

16. Svintsyts'ka NL, Kohut IV, Ustenko RL ta in. Prosvitnyts'ka rol' anatomichnoho muzeyu u formuvanni zdorovoho sposobu zhyttya sered molodi. [Educational role of the anatomical museum in the formation of a healthy lifestyle among young people]. Fizkul'turno-ozdorovchi ta sportyvni tekhnolohiyi $v$ people]. Fizkul'turno-ozdorovchi ta sportyvni tekhnolohiyi v
osvitn'omu prostori: teoriya i praktyka: kolektyvna monohrafiya osvitn'omu prostori: teoriya i praktyka: kolektyvna monohrafiya
za zah. red. OO Momot, YuV Zaytsevoyi. Poltava: PNPU im. za zah. red. OO Momot, YuV Zaytsevoyi. Poltav
V.H. Korolenka, 2020. P. 225-243. (Ukrainian).

17. Svintsytska NL, Korchan NO, Hryn VH ta in. Orhanizatsiya dystantsiynoho navchannya $z$ dystsypliny "Anatomiya lyudyny». [Organization of distance learning in the discipline «Human Anatomy»]. Materialy Mizhnarodnoyi naukovo-praktychnoyi Anatomy»]. Materialy Mizhnarodnoyi naukovo-praktychnoyi
konferentsiyi "Metodyka navchannya pryrodnychykh dystsyplin konferentsiyi "Metodyka navchannya pryrodnychykh dystsyplin
$\mathrm{u}$ seredniy ta vyshchiy shkoli» (XXVIII KARYSHYNS'KI $\mathrm{u}$ seredniy ta vyshchiy shkoli» (XXVIII KARYSHYNS'K
CHYTANNYA). Poltava: Astraya. 2021:276-278. (Ukrainian).

18. Svintsyts'ka NL, Pilyuhin AV, Ustenko RL ta in. Profesor Sherstyuk Oleh Oleksiyovych VDNZU «Ukrayins'ka medychna stomatolohichna akademiya» (m. Poltava). [Professor Sherstyuk Oleh Oleksiiovych VDNZU "Ukrainian Medical Dental Academy» (Poltava)]. Visnyk problem biolohiyi i medytsyny. Academy" (Poltava)]. Visnyk problem biol
Poltava. 2016;2(3;130):10-11. (Ukrainian).

19. Svintsyts'ka NL, Sherstyuk OO, Deyneha TF, Rohulya VO, Hryn VH. Vplyv naukovykh doslidzhen' vykladacha na formuvannya suchasnoho likarya. [Influence of scientific researches of the teacher on formation of the modern doctor]. Osnovni napryamky udoskonalennya pidhotovky medychnykh kadriv u suchasnykh umovakh: materialy Vseukr. nauk.-prakt. konf. z mizhnar. umovakh: materialy Vseukr. nauk.-prakt.

20. Tarasenko YA, Tykhonova OO, Hryn VH ta in. Suchasni aspekty vykladannya anatomiyi lyudyny na osnovi kompetentnisnoho pidkhodu. [Modern aspects of teaching human anatomy based on a competency approach]. Realiyi, problemy ta perspektyvy vyshchoyi medychnoyi osvity: materialy navch.-nauk. konf. z mizhnar. Uchastyu. Poltava, 2021:256-257. (Ukrainian).

21. Zheleznov LM. Professor-anatom I.I. Kositsyn v vospominaniyakh sovremennikov (k 110-letiyu so dnya rozhdeniya). [Professor-anatomist I.I. Kositsyn in the memoirs of his contemporaries (on the occasion of the 110th anniversary of his birth)]. Orenburgskiy meditsinskiy vestnik. 2016; IV(3(15)):7477. (Russian).

\section{Реферат}

СТАНОВЛЕНИЕ И ДОСТИЖЕНИЯ КАФЕДРЫ АНАТОМИИ ЧЕЛОВЕКА ПОЛТАВСКОГО ГОСУДАРСТВЕННОГО МЕДИЦИНСКОГО УНИВЕРСИТЕТА С МОМЕНТА ЕЕ ОСНОВАНИЯ

Гринь В.Г.

Ключевые слова: Полтавский государственный медицинский университет, кафедра анатомии человека, научная работа, ученые-анатомы.

В своем становлении и развитии Полтавский государственный медицинский университет прошел тернистый путь от одонтологического факультета, созданного на базе Харьковской медицинской академии в 1921 году, до ведущего специализированного учреждения по подготовке врачей, который в 2021 году отмечает свой 100-летний юбилей со дня основания. 
В 1950 году кафедра анатомии человека получила свою собственную базу. Научная тематика кафедры охватывала широкий спектр вопросов, была посвящена изучению строения желез слизистых оболочек и вегетативной нервной системы, изучению лимфоидной ткани начального отдела пищеварительной системы, были оборудованы микроскопическая, гистологическая, гистохимическая и фотолаборатории, организован музей кафедры. Учеными были разработаны и изготовлены различные приспособления и методики для проведения морфологических исследований, что позволило опубликовать многочисленные методические рекомендации, учебные пособия, проводить научную работу по защите диссертаций на соискание степени кандидата и доктора медицинских наук.

Украшением кафедры анатомии человека ПГМУ является современный анатомический музей, который в нынешнем виде сформирован в 2005 году, известен за рубежом. Музей вызывает интерес у абитуриентов во время проведения «Дня открытых дверей», принимает студентов-биологов других вузов. В деятельности кафедры анатомии человека тесно сочетаются педагогический процесс и воспитательная работа.

\section{Summary}

BECOMING OF THE DEPARTMENT OF HUMAN ANATOMY AT POLTAVA STATE MEDICAL UNIVERSITY SINCE ITS FOUNDATION AND ITS MAJOR ACHIEVEMENTS

Hryn V. G.

Key words: Poltava State Medical University, Department of Human Anatomy, research work, anatomists.

In its becoming, Poltava State Medical University has passed a thorny path from the odontology faculty, created on the basis of the Kharkov Medical Academy in 1921, to the leading specialized institution for training medical and healthcare professionals. In 2021 the university has celebrated its 100th anniversary. In 1950, the Department of Human Anatomy moved to a new location and dedicated to the training of medical professionals, research activities. The scope of scientific research conducted at the department covered issues on the structure of glands of the mucous membranes, lymphoid tissue of the initial section of the digestive system, structural peculiarities of autonomic nervous system. The department put a lot of effort to equip microscopic, histological, histochemical and photo laboratories, to create the museum of the department. Scientists developed and manufactured various devices and techniques for conducting morphological studies, which made it possible to publish numerous methodological recommendations, textbooks, and to conduct research for the candidate and doctor degrees. The anatomical museum, refurbished and modernized in 2005 and known even abroad is the subject of honour not only for the department, but for the University as well. The museum is also a matter of utmost interest to young visitors during the Open Days, students from other universities. The Department of Human Anatomy seeks to capitalize on a number of pedagogical experiences and research achievements to transfer knowledge and know-how to young generation of students and scientists. 